\title{
Zingiber Officinale and Pure Honey in Overcoming The Invisibility Of Back Pain in Trimester III Pregnant Women
}

\author{
Dewi Nurlaela Sari*, Yanyan Mulyani \\ Faculty of Health Sciences, Universitas Bhakti Kencana, Indonesia \\ *dewi.nurlaela@bku.ac.id
}

\begin{abstract}
Pregnancy is a physiological condition with a unique character. Because not a few of them cause discomfort due to various anatomic and physiological changes during pregnancy. Low back pain is one of the discomfort felt by pregnant women, especially pregnancies that are in the third trimester. 50-80\% of pregnant women complain of low back pain that interferes with pregnancy, and their care is limited to offering pharmacological counseling and therapy. This study aims to determine the effect of Zingiber Officinale and pure honey in the handling of low back pain discomfort in Trimester III pregnant women. This type of research method is a quasi-experiment with one group pre-post test design approach. The sampling method used purposive sampling, namely as many as 51 respondents. The instrument used to measure the level of low back pain in pregnant women was the Oswestry Disability Index (ODI) and the bivariate test used was the Wilxocon test with paired t-test. The results showed that offering food and honey was effective in reducing the low back pain scale in pregnant women with a p-value (2-tailed) of $0.000(\mathrm{p}<0.05)$. In conclusion, it is found that there is an effect of offering female labor and pure honey in the management of low back pain in third-trimester pregnant women. It is hoped that the results of this study can be used as the basis for policies regarding the care of pregnancy discomfort with back pain by presenting complementary.
\end{abstract}

Keywords: Honey, Low Back Pain, Pragnancy, Zingiber Ofiicinale 


\section{STRADA Jurnal Ilmiah Kesehatan}

DOI: $10.30994 /$ sjik.v9i2.481

ISSN: 2252-3847 (print); 2614-350X (online)

Vol.9 No.2 November 2020 Page.1403-1408

\section{BACKGROUND}

Continuity of care is a preventive measure and early detection to deal with complications or maternal discomfort that may occur during pregnancy until the puerperium. (DT Murti, 2019). Antenatal care (ANC) is the first step, with optimal ANC it is hoped that the quality of life for pregnant women and babies can run better. One of the factors that can affect the quality of life of pregnant women is the discomfort of pregnancy, as a result of physiological and psychological changes in the body's systems. Low back pain is a discomfort in pregnant women with a high percentage, especially when pregnancy is in the third trimester, which is around 50-80\%. (Hani, 2018)

Low back pain in pregnant women is generally influenced by weight gain, spinal physiology, and changes in body posture due to an enlarged uterus. (Schroder et al, 2016). Complications of low back pain are limited mobility of pregnant women. This immobility causes the blood flow to slow down in the veins and increases the occurrence of blood clots, putting the mother at the risk of developing venous thrombosis. (Hollingworth, 2011)

Midwifery care for low back pain is currently limited to pharmacological counseling and therapy with the administration of $500 \mathrm{mg}$ calcium tablets. Meanwhile, there are nonpharmacological therapies that can be developed by midwives in providing care, namely by using endorphins massage therapy, pregnancy exercise, the use of ginger, and relaxation with the help of aromatherapy. (Robson, 2012)

Ginger (Zingiber Officinale) is an easily available plant. Ginger has analgesic, antipyretic, anti-inflammatory, antiemetic, anti-rheumatic benefits, increases body resistance, and has antioxidant properties whose activity is higher than vitamin E. Ginger contains strong compounds such as gingerols, polyphenols, flavonoids, tannins, and vitamin C. (Margono, 2016 )

The use of ginger in midwifery care is limited to antiemetics. This is supported by research that offering ginger drink can reduce the frequency of morning sickness from 13 times to 3 times. There are no studies on the use of ginger as an analgesic, especially in dealing with low back pain in pregnant women. Ginger can be given in the form of a spread (oil), aromatherapy, extracts, and warm drinks. How to process ginger into a warm drink that is felt to be quite effective because it can be done by pregnant women anywhere at affordable costs. Processed ginger can be added with pure honey to add flavor. Besides, pure honey has ingredients that are beneficial for pregnant women. Honey is antioxidant and antibacterial. (Aggad, 2014)

\section{METHODS}

A quasi-experiment is a research method used with a one-group pre-post test design approach. Its purpose is to examine cause-and-effect relationships with treatment or intervention. This research was conducted by grouping respondents or subjects and then observing them before and after the intervention (giving ginger and honey). (Nursalam, 2013) Pregnant women with low back pain were the population of this study with a total sample of 51 respondents. Sampling is done by purposive sampling technique which is based on certain considerations based on the characteristics or characteristics of the population that have been previously known. Notoatmodjo, 2018. The intensity of low back pain was measured using the Oswestry Disability Index (ODI). Before and after the intervention was carried out. The bivariate test used was the Wilxocon test with a paired ttest. 


\section{STRADA Jurnal Ilmiah Kesehatan}

DOI: $10.30994 /$ sjik.v9i2.481

ISSN: 2252-3847 (print); 2614-350X (online)

Vol.9 No.2 November 2020 Page.1403-1408

\section{RISULTS}

Based on research conducted on 51 respondents to pregnant women with the discomfort of pregnancy low back pain trimester III. The following results were obtained.

Table 1. Level of Low Back Pain in Third Trimester Pregnant Women Before Intervention

\begin{tabular}{clcc}
\hline No & Pain Level & $\begin{array}{c}\text { Frequency } \\
\text { Pre-test }\end{array}$ & $\begin{array}{c}\text { Percentage (\%) } \\
\text { Pre-test }\end{array}$ \\
\hline 1. & No Pain & 0 & $0 \%$ \\
2. & Mild Pain & 0 & $0 \%$ \\
3 & Moderate Pain & 27 & $52,9 \%$ \\
4. & Severe pain & 24 & $47,1 \%$ \\
5. & Very Severe Pain & 0 & $0 \%$ \\
\hline & Total & $\mathbf{5 1}$ & $\mathbf{1 0 0 \%}$ \\
\hline
\end{tabular}

Based on table 1, it can be seen that most respondents experienced moderate pain before giving ginger and honey with the number of respondents being 27 pregnant women $(52.9 \%)$.

Table2. Level of Low Back Pain in Third Trimester Pregnant Women After Intervention

\begin{tabular}{clcc}
\hline No & \multicolumn{1}{c}{ Pain Level } & $\begin{array}{c}\text { Frequency } \\
\text { Pre-test }\end{array}$ & $\begin{array}{c}\text { Percentage (\%) } \\
\text { Pre-test }\end{array}$ \\
\hline 1. & No Pain & 5 & $9,8 \%$ \\
2. & Mild Pain & 36 & $70,6 \%$ \\
3 & Moderate Pain & 10 & $19,6 \%$ \\
4. & Severe pain & 0 & $0 \%$ \\
5. & Very Severe Pain & 0 & $0 \%$ \\
\hline \multicolumn{2}{r}{ Total } & $\mathbf{5 1}$ & $\mathbf{1 0 0 \%}$ \\
\hline
\end{tabular}

Based on Table 2, it can be seen that most of the respondents experienced mild pain after being given the intervention of pure ginger and honey. Of the 51 respondents, 17 people (33.3\%) experienced a decrease from the severe pain scale to mild pain, and 5 people $(11.8 \%)$ who experienced moderate pain decreased to no pain.

Table 3. Effect of Zingiber Officinale and Pure Honey in Overcoming Pregnancy Discomforts of Low Back Pain

\begin{tabular}{|c|c|c|c|c|c|}
\hline \multirow{2}{*}{$\begin{array}{l}\text { Tingkat } \\
\text { Nyeri }\end{array}$} & \multicolumn{2}{|c|}{ Pre-Test } & \multicolumn{2}{|c|}{ Post-Test } & \multirow[t]{2}{*}{ Sig (2-tailed) } \\
\hline & $\mathrm{F}$ & $\%$ & $\mathrm{~F}$ & $\%$ & \\
\hline No Pain & 0 & $0 \%$ & 5 & $9,8 \%$ & \\
\hline Mild Pain & 0 & $0 \%$ & 36 & $70,6 \%$ & \\
\hline Moderate Pain & 27 & $52,9 \%$ & 10 & $19,6 \%$ & \\
\hline Severe pain & 24 & $47,1 \%$ & 0 & $0 \%$ & \\
\hline Very Severe Pain & & & & & \\
\hline Total & 51 & 100 & 51 & 100 & $\mathbf{0 , 0 0 0}$ \\
\hline
\end{tabular}




\section{STRADA Jurnal Ilmiah Kesehatan}

DOI: $10.30994 /$ sjik.v9i2.481

ISSN: 2252-3847 (print); 2614-350X (online)

Vol.9 No.2 November 2020 Page.1403-1408

Based on Table 3, it is known that after the intervention of ginger and honey there was a decrease in pain levels. From a total sample of 51 people before the intervention, 27 people (52.9\%) were known to be in pain and 24 people $(47.1 \%)$ had severe pain. The results of the study, out of 27 respondents who experienced moderate pain, the pain level decreased to 5 people $(11.8 \%)$ who did not experience pain, 18 people $(35.2 \%)$ experienced mild pain, and 3 other people (5.9\%) still at moderate pain levels. Based on the results of the study, 24 respondents who previously experienced pain also experienced a decrease in pain levels where 17 people (33.3\%) experienced a decrease to mild pain, and 7 other people $(13.8 \%)$ experienced moderate pain.

\section{DISCUSSION}

The process of pregnancy will cause various changes in all body systems, these changes have an impact on the cardiovascular system, respiratory system, hormonal system, gastrointestinal system, and musculoskeletal system. (Potter\&Pery, 2010) Some of the discomforts that arise in the third trimester, usually a pregnant woman urinating $50 \%$, experiencing constipation $40 \%$, and flatulence $30 \%$, then $15 \%$ vaginal, then experiencing swelling in the legs $20 \%$, cramps in foot $10 \%$, headache $20 \%$. Then striae gravidarum $50 \%$, hemorrhoids $60 \%$, shortness of breath $60 \%$, and low back pain $70 \%$ (Puspasari, 2019)

One of the discomforts in pregnant women is low back pain which has the highest proportion of pregnancy in the third trimester. As many as 50-80\% of pregnant women complain of low back pain which is quite disturbing during pregnancy. Low back pain is felt most between the fifth and seventh months of pregnancy (20-28 weeks). The two most common types of back pain are lumbar and sacral/pelvic pain. Lumbar pain tends to be felt in the middle of the lumbar vertebrates but can also radiate to the legs. Sacral / pelvic pain is four times more common in lumbar pain pregnancies. Pain can radiate to the pubis and down the buttocks to the back of the thigh. One-third of sufferers will continue to suffer from low back pain for 4 weeks after delivery and one-sixth of sufferers, 9 weeks after delivery. (Hollingworth, 2011).

Complications of low back pain are deterioration of mobility which can inhibit activities that cause vehicles, caring for children and affect mother's work, insomnia which causes fatigue and irritability. Pain may appear in certain activities only or be so severe, limited mobility of pregnant women. Immobility will slow down blood flow in the veins and increase the process of blood clotting so that the mother is at risk of developing venous thrombosis. While pain is with her, consult a doctor, and do further tests, this condition can be a sign of infection in the kidneys or bladder. Infection of the kidney or bladder in pregnant women can cause various complications in the unborn baby, one of which is the baby born prematurely. (Kemkes RI, 2016)

Efforts to deal with low back pain are pharmacological and non-pharmacological. Pharmacological therapy can be given $500 \mathrm{mg}$ calcium tablets. Non-pharmacological care that can be given to low back pain patients is providing relaxation, consuming foods, or drinks that can reduce back pain such as ginger. (Herawati, 2017)

The administration of Zingiber officinale and honey can reduce pain because the therapy provides a relaxing effect by reducing muscle tone. When the body is comfortable and relaxed, endorphins are naturally released. This hormone provides a natural pain relief (analgesic) effect from the body.

According to Rakel (2002), Low Back Pain (LBP) is low back pain that originates from the spine, nerves, or other structures in the area. Thus, low back pain is a 


\section{STRADA Jurnal Ilmiah Kesehatan}

DOI: $10.30994 /$ sjik.v9i2.481

ISSN: 2252-3847 (print); 2614-350X (online)

Vol.9 No.2 November 2020 Page.1403-1408

musculoskeletal disorder in the waist area caused by various diseases and poor body activity. Tanama Ginger (Zingiber officinale) has quite a variety of uses, including as a spice, essential oil, flavoring agent, or as a medicine (Bartley and Jacobs 2000). According to Stoilova (2007), the chemical components of ginger contain chemicals such as gingerol, school, and zingerone which are useful for providing pharmacological and physiological effects such as antioxidants, anti-inflammatory, analgesic, anti-carcinogenic, non-toxic, and non-mutagenic even at high concentrations. According to research Akoachere (2002) shows that consuming fresh and processed ginger every day will reduce muscle pain and prevent muscle wrong due to exercise. In this study, researchers made use of ginger by drying it and then making it into a powder. The result of the collision is then brewed with warm water added with honey in a ratio of 0.15 grams of powdered ginger and 5 grams of honey, brewed with $150 \mathrm{ml}$ air. When the intervention respondents were carried out, they felt comfortable and warm when consuming the drink, so they forgot about the pain. From a 5-day evaluation, it is shown that Zingiber officinale can reduce the intensity of low back pain. Ginger has a pharmacological effect, namely hot and spicy, where this feeling of heat can relieve pain, stiffness, and muscle spasm or vasodilation of blood vessels, the maximum benefit will be achieved within 20 minutes after heat application (Susanti, 2014). Besides, the warm effect can relax muscles, inhibit the inflammatory process, give a feeling of comfort, release endorphins, and inhibit the transmission of pain impulses to the brain.

The analgetic effect of ginger is relaxing. This effect is continued to the hypothalamus and produces the hormone Corticotropin-Releasing Factor (CRF). The CRF hormone will stimulate the pituitary gland to increase Proopioidmelano Cortin (POMC) which can cause the production of enkephalin by the adrenal medulla to increase. Also, the pituitary gland also produces endorphins as a neurotransmitter that can affect mood to relax so that low back pain is reduced. (Guyton and Hall, 2014)

The effect of ginger to reduce pain intensity is related to thromboxane inhibition and the presence of prostaglandin activity. Low back pain is a result of weight gain and spinal physiology besides that an enlarged uterus will increase the degree of lordosis. The results of a 2009 study showed that ginger was as effective as mefenamic acid and ibuprofen in relieving pain. The results of research in 2001 also showed that the salicylates in fresh ginger have pain relief and anti-inflammatory effects, and can be used to treat smooth muscle disorders. 4 Also, giving ginger is also concluded to reduce pain. The addition of honey as an antibacterial will increase the immunity of pregnant women and coping with pain will be better.

\section{CONCLUSION}

Based on the results of research that has been conducted on the use of medical personnel and pure honey in overcoming the discomfort of lumbago pregnancy in trimester III pregnant women, there is a significant effect with a significant $\mathrm{p}$-value of 0.000 . It is hoped that the results of this study can be used as the basis for policies implementing complementary therapies in pregnancy.

\section{REFERENCES}

DT Murti, 2019. Asuhan Kebidanan Berkesinambungan pada Ny. F Usia 26 Tahun G2P1Ab0Ahl dengan Kehamilan Normal di Puskesmas Godean 1 Sleman. Poltekes Kemenkes Jogja ; http://eprints.poltekkesjogja.ac.id/id/eprint/1535

Guyton and Hall. 2014. Buku Ajar Fisiologi Kedokteran. Singapore : Elsevier 


\section{STRADA Jurnal Ilmiah Kesehatan}

DOI: $10.30994 /$ sjik.v9i2.481

ISSN: 2252-3847 (print); 2614-350X (online)

Vol.9 No.2 November 2020 Page.1403-1408

Hanni, U. 2018. Asuhan Kebidanan Pada Fisiologis Kehamilan. Jakarta : Salemba Medika Herawati, I., \& Wahyuni. 2017. Pemeriksaan Fisioterapi. Surakarta: Muhammadiyah University Press.

Hollingworth, T. 2011. Diagnosis Banding Dalam Obstetri Dan Ginekologi, Jakarta ; EGC.

Kemenkes RI. 2016. Keperawatan Medikal Bedah. Jakarta :Badan Pengembangan dan Pemberdayaan Sumber Daya Kesehetan Kemenkes RI.

Margono. 2016. Pengaruh Terapi Zingber Officinale Terhadap Intensitas Nyeri Low Back Pain di Posyandu Margomulyo Desa Ngrancah Kecamatan Grabag. Jurnal Keperawatan Muhammadiyah. 1 (1) Low Back Pain Di Posyandu Margomulyo Desa Ngrancah Kecamatan Grabag. Jurnal Keperawatan Muhammadiyah. 1(1), 5862.

Mantiri, N. C., Awaloei, H., \& Posangi, J. (2013). Perbandingan Efek Analgetik Perasan Rimpang Jahe (Zingiber officinale var. rubrum Thelaide) dengan Aspirin Dosis Terapi pada mencit (Mus musculus). Jurnal E-Biomedik (EBM), 1(1), 518-523.

Notoatmodjo. 2018. Metodelogi Penelitian Kesehatan. Jakarta: Salemba Medika.

Nursalam. 2013. Metodologi Penelitian Ilmu Keperawatan Edisi 3. Jakarta: Salemba Medika.

Potter, P. A, Perry , A. G. 2010. Buku Ajar Fundamental Keperawatan Konsep, Proses, dan Praktik. Edisi 7, Buku ketiga. Jakarta: EGC

Puspasari. 2019. Pengaruh Endorphine Massage Pada Pengurangan Rasa Nyeri Punggung Pada Ibu Hamil Trimester Iii Di Pmb Cicih Rukaesih Tahun 2018. Sekolah Tinggi Ilmu Kesehatan (STIKes) Cirebon; Jurnal Ilmiah Indonesia ,Vol. 4, No.3

Rahmawati, I. (2016). Pengaruh Pemberian Minum Jahe Hangat dengan Intensitas Nyeri pada Persalinan Kala I di Rsia Kumalasiwi Kabupaten Jepara. Jurnal Kebidanan Universitas Muhammadiyah Semarang, 5(2), 7

Robson, S., E., \&Jason. 2012. Patologi Pada Kehamilan: Manajemen \& Asuahan Kebidanan. Jakarta: Buku Kedokteran EGC.

Sastroasmoro, S., Ismael, S. 2016. Dasar-dasar Metodologi Penelitian Klinis. Jakarta ; Karisma

Schroder, G., Kundt, G., Otte, M., Wendig, D.,\&Schober, H. C. (2016). Impact Of Pragnancy On Back Pain and Body Poatur in Mowen. The Journal of Phsiology. $\underline{28}(4)$

Susanti, D. (2014). Pengaruh Kompres Hangat Jahe terhadap Intensitas Skala Nyeri Osteoarthritis pada Lansia di Panti Sosial Tresna Werdha Kasih Sayang Ibu Batu Sungkar 2014. Fakultas Kesehatan dan MIPA Universitas Muhammadiyah Sumatera Barat, Padang

Yoo, H., Shin, D.,\& Song, C. 2015. Changes In The Spinal Curvature, Degree of pain, Balance Ability, And Gait Ability According To Pregnancy Period In Pregnant And Nonpregnant Women. The Journal of Phsiology. 27 (1) 